\title{
Commercialization unsustainable to Himalayan environment
}

\author{
Gopal S. Singh \\ Institute of Environment and Sustainable Development, \\ Banaras Hindu University, Varanasi 221005, UP, India \\ e-mail: gopalshs@yahoo.co.in
}

\begin{abstract}
Indigenous people of north western Himalayan region of India utilize a wide range of biological resources for subsistence. The age-old practices of resource utilization have supported the rural economy with equity and social justice and conservation of resources since generations. However, in recent times, due to market demand, the biological resources are subjected to premature and frequent harvesting of ruthless exploitation by unskilled people particularly from outskirt of people. In addition to this, unfavorable government forest policy and ignoring people's participation in decision-making and changing climatic conditions are some of the prime factors responsible for changing traditional resource management practices. Over increasing population pressure demand lead for market oriented commercial demand has resulted in over-exploitation of some of the plant resources at alarming pace. This calls for the development of resource management techniques built up on traditional knowledge capable of meeting the challenges of conservation on the one hand and socio-economic development of the local people on the other. Changing indigenous resource management practices in north western Himalaya imperils herbal based health care system and livelihood pattern.
\end{abstract}

Key worlds: commercialization, apple, high yielding variety, traditional knowledge, biodiversity, resource conservation, sustainable development, Himachal Pradesh, Indian Himalaya.

\section{Introduction}

The Indian Himalaya, spreading about $2500 \mathrm{~km}$ in length and $250 \mathrm{~km}$ in width, covers $18 \%$ of the geographical area of India. It nurtures more than $50 \%$ of India's forest cover to which $40 \%$ of the species are endemic to Indian subcontinent (Singh 1999b). Conservation of the biological resources of the Himalaya is important from local as well as national/goal stand point of sustainable development (Singh 1999b). North-western Himalaya occupies about $11 \%$ of total geographical area of Himalaya, where $92 \%$ population is rural and practices subsistence farming activities. Agriculture of this area as elsewhere in the Himalaya is crop and livestock mixed farming system largely depend on surrounding forest based resources an is the prime economic activity of the people (Ramakrishnan et al. 1994). Introduction of high yielding varieties (HYVs) of food crops and fruit producing trees is a recent phenomenon (Singh 1998; Singh et al. 1997b). In the past, there used to be little pressure on forest-based-resources resulting into a perfect balance between exploitation and regeneration of natural resources but, ever-rising human population and higher economic aspirations due to market interventions have interrupted this harmonious relationship of resource use. Most of the earlier studies from north western Himalaya, mostly described traditional knowledge of resource use form ethnobotanical angle (Bhattachary 1991; Singh 1999a). No attempt has so far been made to evaluate the factors responsible for the breakdown of age old traditional practices and consequently the over-extraction of natural resources. This study will, therefore, analyze the indigenous practices of natural resource use, effect of commercialization on natural habitats/resources and the role of existing forest policy in the conservation of resources in Chhakinal watershed in Kullu district of north western Himalaya, India. 


\section{Study area}

The study area lies at $32^{\circ} \mathrm{N}$ and $77^{\circ} \mathrm{E}$ in the heart of Kullu district of State of Himachal Pradesh, covering a geographical area of about $45 \mathrm{~km}^{2}$. The altitudinal gradient varies between $1500 \mathrm{~m}$ in valley to 4500 at hill-tops characterizes sub-montane to montane types of climate. The area receives average $1200 \mathrm{~mm}$ rainfall annually. Settlements and agricultural activities are confined up to $2300 \mathrm{~m}$. There are 10 villages with a total population of 2340 . The prime source of economy is agriculture and animal husbandry.

\section{Results and discussion}

\subsection{Traditional techniques of plant resource collection and processing}

Local people involved in collection and gathering of medicinal herbs are extremely skillful in identification, processing, grading, trading and usage. The method of collection generally involves using a locally derived sharp-edged trowel but people often be seen a variety of collection procedures and processes through trial and error process. For example, fine roots, leaf scars and soil particles were removed from main roots and rhizomes prior to slicing them into small pieces and sun drying. If weather is not clear then the plant is dried with the help of some/fire either in forests or at home. Different parts of plants are dried differently. It is believed that Aconitum heterophyllum roots dried directly in sun light would lead to the depredation of its active ingredients. Similarly, the root bark of Juglans regia is peeled off and immediately folded in small pieces of about $10 \mathrm{~cm}$ in length and is dried in sun light. Chains of Morchella esculenta are prepared with the help of needle and thread and tagged in the roof of kitchen for a period of $10-15$ days.

The techniques of drug preparation are very simple. Powders and pastes are prepared with the help of locally designed flat stones and pestles. Small pieces of clean cloth are used to extract juices.

\subsection{Diversity and usage of natural resources}

A total of 134 plant species were recorded from the study area. These species are distributed within the altitudinal range of $1600 \mathrm{~m}$ to $4000 \mathrm{~m}$ encompassing coniferous species at lower to middle zone and broad leaf bearing tree species at higher elevation, alpine region is devoid of trees. Maximum numbers of herbaceous species were recorded from the alpine region whereas minimum from lower zone covered in coniferous forests specially Pinus roxburghii tree species. Medicinal plants are abundantly found in the alpine area above $2500 \mathrm{~m}$ amsl.

A total of 134 plant species are used for various purposes in the study area. Of this, 73 species are used for various medicinal purposes in the study area. Thirty two are used to cure various stomach ailments, 13 for boils, 10 as pain killers, 5 each for curing gums, fever and diuretic problems, 2 in pregnancy, while one in cancer treatment (Table 1). Leaves, stems, flowers, fruits, seeds, bark, roots, tubers an rhizomes are the plant parts used for curing different ailments in the form of powder, paste, juice, decoction, infusion an direct/fresh plant parts. According to the nature of ailments and type of plants, 2-5 doses are recommended daily; morning and evening usage are common; the dose of the medicine is generally one full tea spoon for adults and half tea spoon for children. If a patient is not cured from one kind of remedy during a specific period of time, then another remedy is suggested.

Similarly, 34 plant species are valued for flood in the form of spices, condiments, vegetables and fruits; 19 for dye materials, fiber, bamboo articles, incense, and soap; 21 for fuel wooed; 14 for fodder and 7 species of organic manure preparation which is a mixture of leaf litter and livestock excreta. Some of the plant species are sued more than one purpose.

Table 1. Usage of forest based resources in the study area

\begin{tabular}{|l|c|}
\hline \multicolumn{1}{|c|}{ Use category } & $\begin{array}{c}\text { No. of } \\
\text { Plant } \\
\text { species }\end{array}$ \\
\hline Medicinal plants & 32 \\
Stomach problems & 13 \\
Boils, cut and wounds healing & 10 \\
Pain killer & 5 \\
Gum and teeth diseases & 6 \\
Cold and cough & 6 \\
Eye problems & 5 \\
Fever & 5 \\
Diuretic problems & 2 \\
Child birth & 1 \\
Cancer & 34 \\
\hline Food items & 19 \\
\hline Household items & 21 \\
\hline Fuel wood & 14 \\
\hline Fodder & 7 \\
\hline Animal beddings & \\
\hline
\end{tabular}




\subsection{Role of forest policy}

The forest National Forest Policy (NFP) of the Government of India of 1952 had provided basis platform to frame State Forest Policy (SFP) of the Government of Himachal Pradesh in 1980. To preserve and protect the forests of the State, various rules and acts were enacted. These legislations were primarily focused to protect the forest and simultaneously earn economy after selling timber therefore, forest agency is getting benefited. Local people could not get any benefit in such process. Legislation favoring to the management of minor forest products and medicinal plants was un-emphasized considering these resources as minor products. Earlier, these resources were managed by the village panchayats/councils. Since 1964, village council was empowered to change the royalty on the village agents those involved in trade of the minor forest produce. However, gatherers/villagers, village council as well agents were not required to pay any revenue to the forest department. The income generated from this scheme was to be used for village development. In such incentive based initiative, the conservation of natural resources was the responsibility of the village council. But, this peopleoriented management practice was over taken by the forest department.

The forest department commenced insuring export permits in 1978 to those who sent medicinal plant material elsewhere those who want to send medicinal plant material outside for selling purpose. The fee for export permit was very nominal. Rupees five was charged per export permit irrespective of quantity and type of materials were being exported. However, in 1993, Government has enhanced the fee drastically (1999b). Until 1993, there were only 14 plant species for which export permit was issued but now permission has been granted for about 42 plant species for commercial utilization. Of these, 30 species were found in the study area and currently 22 species are being exported/ marketed. The enhancement has certainly accelerated the commercial collection of medicinally important plants at large scale. Present forest policy mostly favoured to financial gain rather than focusing to conservation of minor forest produce of local importance. Thus, policy favouring to commercialization of medicinal herbs has further aggravated the problems of habitat destruction. Hence, it has become indispensible to find out new options/policy emphasizing conservation of minor forest resources and drug plants.

\subsection{Impact of commercialization}

Commercialization of natural resources has led to reckless extraction. Earlier, collection of medicinal plants was done by local people well known to species but policies favouring to monetary benefit and simultaneously rising market demand have favoured the ruthless gathering by outsiders unknown to the biology of medicinal plants which has further threatened the existence of these valuable plants. This has resulted in receding the herbal resources from the area. Many evidences related to dramatic decline in quality and quantity of medicinal herbs was recorded from the villagers (Box 1). Tone of the reason often given was premature and frequent harvesting by unskilled people not aware about the physiology of plants. Size of underground parts of Jurinea macrocephala has become smaller because of frequent and premature harvesting. Traditionally, rhizomes/tubers of Saussurea lappa, Picrorrhiza kurrooa, Jurinea macro-

Box 1. Evidence of the over-exploitation of medicinal plants

\begin{tabular}{|l|}
\hline \multicolumn{1}{|c|}{ Attributes } \\
\hline Increase in time and labour involved in collection \\
More distance travel to gather medicinal plants \\
Problem in getting some of the medicinal plants \\
More number of involvement of person (per family) for collection \\
Extraction of medicinal plants before maturation \\
Disappearance of medicinal plants close to settlements \\
Poor regeneration results low availability \\
Reduction in yield (root material) of some of medicinal plants \\
Climate change responsible for reduction in medicinal plants availability \\
Impact of over-increasing population pressure on over-exploitation \\
Role of market demand in over-extraction \\
Unscientific way of collection \\
Reduction in area available for litter collection due to loss of forest cover \\
Reduction in fodder availability result loss of fodder tree species due to agriculture expansion \\
More time and labour involved in fuel wood, fodder and litter collection due to loss of nearby forest cover \\
\hline
\end{tabular}


cephala and Aconitum heterophyllum were harvested after the gap of 2-3 years to get quality yield without jeopardizing their regeneration potential but now these are harvested every year resulting in poor regeneration (Singh 1999b). Excessive harvesting is alarming impact on other species too. Species such as Morchella exculenta and Dioscorea deltoidea were once found in abundance are now very difficult to get. Similarly, Dactylorhiza hatagirea, Ainsliaea aptera and Aconitum heterophyllum are very difficult to located Saussurea lappa has come under threatened category and it is likely to disappear from natural habitat.

Now if one turns to agriculture, commercialization by introduction of HYVs of food and fruit crops which require high doses of agro-chemicals has negative impacts on native plant resources of food, fodder, fuel and medicinal values (Ram \& Singh 1997; Singh 1998). Expansion of agricultural area into the forests is one another threat of natural habitat destruction. Plants of medicinal value occurred naturally in and around the farm fields are disappearing in wake of extensive and intensive cultivation.

\subsection{Commercialization vis-à-vis sustainability}

As mentioned in the foregoing the local use of plant resources for subsistence contributes to the conservation of species and habitats and can be used as the basis for conservation policies geared forward indigenous management regimes and utilization. In the past, there used to be little population pressure on the land and other natural resources resulting into a perfect balance between environment and society but, increasing population pressure, higher economic aspirations and forest policy favouring commercial exploitation has interrupted the harmonious relationship between mountain societies and available natural resources. Increasing market values of herbal resources and farming practices have upgraded the economic prosperity of the local people at the cost of environmental un-sustainability. For instance, as sporadically pointed out commercialization has not only changed crop cultivation, cropping patterns, cropping sequences, land use land cover, socio-economic and socio-cultural milieu drastically but has simultaneously induced soil erosion, heterogeneity in climatic attributes such as temperature and humidity, receding agro-biodiversity, shrinking forest resources, and deteriorating habitats, these changes are imposing unsustainability to Himalayan environment at irreparable environmental cost.

\subsection{Conservation and management policy}

Government programmes are always focused to the management of timber producing tree species for commercial/ industrial benefits (Singh 1999b). In principle, minor forest products can be harvested without damaging regeneration of natural ecosystem based on traditional methods. Infor- mation related to various stages on trade should be collected and made available to the villagers. Further, value addition, for example the processing of medicinal produce and marketing channels need to be renovated. a new system of regeneration, cultivation and domestication should be evolved. In early forties, medicinal plants like Saussurea lappa, Inula racemosa and Carum carvi were introduced for cultivation in Lahaul and Spiti district, making the state for the largest grower of these important species and producer of drugs obtained from these species (Anonymous 1993; Singh et al. 1997a). Forest policy is not favouring cultivation of such medicinally important plants at commercial level (Singh et al. 1997a). These plants may be cultivated at higher altitude in the farmer's fields and community lands. For strengthening overall sustainability, there is a need to reorient indigenous knowledge, empower local institutions, introduce scientific ways of collection processers, establish linkages with Government agencies and non-government organizations (NGOs), support of basic infrastructure, transparency in marketing channels and conservation supportive forest policies in favour of locals can encounter pressure on natural resources. Further, incentives for cultivation of medicinal plants and local crops and rejuvenation of traditional knowledge and involvement of the whole village community in decision-making could be the options of mitigating commercial exploitation of forest resources. Establishment of plantations of fodder and medicinal species in degraded lands around settlements could complement to conservation (Dobriyal et al. 1997; Maikhuri et al. 1998).

\section{References}

Anonymous, 1993, Forest of Himachal Pradesh, Department of Forests, Farming and Conservation, Shimla, HP.

Bhattacharya A., 1991, Ethnobotanical observations in the Ladakh region of northern Jammu and Kashmir State, India, Economic Botany 45: 305-308.

Dobriyal R. M., Singh G. S., Rao K.S. \& Saxena K. G., 1997, Medicinal plant resources in Chhakinal watershed in the north western Himalaya, J. Herbs, Spices and Medicinal Plants 5: 15-27.

Maikhuri R. K., Nautiyal S., Rao K. S. \& Saxena K. G., 1998, Medicinal plant cultivation and biosphere reserve management: a case study from the Nanda Devi Biosphere Reserve, Himalaya, Current Science 74: 157163.

Ram S. C. \& Singh G. S., 1997, Grewia oppositifolia time of revival in Himalaya, Agroforestry Today 9: 14-15.

Ramakrishanan P. S., Purohit A. N., Saxena K. G. \& Rao K. S., 1994, Himalayan Environment and Sustainable 
Development, Diamond Jubilee Publication, INSA, New Delhi.

Singh G. S., 1998, Environmental, ecological and socioeconomic impact of introduced crops in western Himalaya: a case study of Kullu valley, J. Human Ecology 9: 63-72.

Singh G. S., 1999a, Ethnobotanical study of useful plants of the Kullu district in north western Himalaya, India, J. Econ. and Tax. Bot. 23: 185-198.

Singh G. S., 1999b, Utility of non-timber forest products in a small watershed in the Indian Himalayas: the threat of its degradation, Natural Resources Forum 23: 65-77.
Singh G. S., Ram S. C. \& Kuniyal J. C., 1997a, Changing traditional land use pattern in the Great Himalaya: a case study of Lahaul valley, J. Environmental Systems 25: 195-211.

Singh G. S., Rao K. S. \& Saxena K. G., 1997b, Energy and economic efficiency of the mountain farming system: a case study in the north western Himalaya, J. Sustainable Agriculture 9: 25-49. 